\title{
Comparative analysis of gender involvement in agricultural production in Nigeria
}

\author{
Mohammed, B. T.* and Abdulquadri, A. F. \\ Human Resources Development Department, National Centre for Agricultural Mechanization (NCAM), P.M.B. 1525, \\ llorin, Nigeria. \\ Accepted 9 March, 2012
}

\begin{abstract}
Agricultural sector is still the leading sector in Nigeria's ailing economy as it provides direct employment to about $75 \%$ of the population. This paper examines gender involvement in agricultural production as a means towards increased food sufficiency and consequently curbing food crisis. It critically identified the specific gender involvement in agriculture and gender inequality is noticed in the sector and this constitutes a bottleneck to development, calling for a review of government policies on agriculture to all the elements that place women farmers at a disadvantage. The study made use of secondary data which was analyzed by simple descriptive statistics. The result revealed that involvement of both sexes in various field activities may be sex specific, but they are complimentary and reciprocal. The study further revealed that the involvement of women was on the increase (from 32 to $36 \%$ ), while that of men declined relatively (from 68 to $64 \%$ ). It was suggested that to curb food crisis and increase the participation of gender in agriculture, there is the need for advocacy for equitable integration of both men and women in agriculture.
\end{abstract}

Key words: Nigeria, gender, agriculture, food crisis.

\section{INTRODUCTION}

In Nigeria, agriculture is the most important sector of the economy from the standpoint of rural employment, sufficiency in food and fibre, and export earning prior to the discovery of oil. Agricultural sector is still the leading sector in Nigeria's ailing economy. It provides direct employment to about $75 \%$ of the population (NBS, 2007). Unlike what used to be in the 70 s and 80 s when agriculture contributed about two-third of the country's Gross Domestic Product (GDP) presently, agriculture contribution to Nigeria's GDP is about $37.2 \%$ (CBN, 2006). Presently, the sector accounts for only $44 \%$ of Nigeria's total exports and $56 \%$ of total non-oil export as compared to 70 s when over $85 \%$ of Nigeria's foreign exchange earnings came from exports of agricultural products. Also, agricultural output has increased less

${ }^{*}$ Corresponding author. E-mail:

bolarindemohammed@yahoo.com rapidly than the estimated population growth rate of $2.8 \%$ per annum while agriculture growth rate is $2.0 \%$. On current global food crisis, one of the glaring effects of the situation in Nigeria has been persistent increase in food importation. Over the past two or three decades, considerable research has been done on gender - related issues in Nigerian agriculture. This has had some impact on policy formulation and programming, including perhaps the creation of women in agriculture (WIA) units in several State and Federal Government Ministries of Agriculture and the Agricultural Development Projects (ADP) in Nigeria. It is however difficult to gauge how effective this has been, especially in terms of moving agriculture forward. All indications are, however, that the success attained in this regard is minimal. Globally, it is evidenced that one of the major problems confronting mankind in recent times is food crisis. This has been one of the reasons why the present administration in Nigeria has devoted two of its reforms on the seven point agenda (food security and land reforms) to bring some changes 
to the agricultural sector in the country. Therefore, the need for more gender participation in agriculture cannot be over emphasized so as to wage war against the food crisis.

The overall objective of this study is aimed at assessing the role of male and female gender in agriculture production in Nigeria. The essence is to identify the specific gender involvement and the needs not to discriminate in the available resources aimed at curbing food crisis and sustain agricultural production in the country. Also to ensure that research and extension in developing and transferring relevant agricultural technologies would not be gender biased. It will also sharpen the focus of advocacy for equitable integration of women and men in agricultural production to curb food crisis and sustain agricultural production in the country. In an effort to reach and engage the poor, we must recognize that some issues and constraints related to participation are gender-specific and stem from the fact that men and women play different roles, have different needs and face different challenges on a number of issues and at different levels.

\section{METHODOLOGY}

The study made use of secondary data obtained from CBN statistical bulletin on gender involvement in agriculture in Nigeria from 1995 to 2006. Descriptive statistics was used to analyze the data. Nigeria has a population of about 140 million people with about 72 million male and 68 million female (NPC, 2006). It has an annual rainfall of 400 to $600 \mathrm{~mm}$. Agriculture is one of the major occupations of the majority of the people. The climate is tropical with distinct rainy season and dry season. Specifically, this study was conducted to encourage more gender involvement in agricultural production and to eliminate food crisis.

\section{RESULTS AND DISCUSSION}

\section{Gender involvement in agriculture}

In Nigeria of about 140 million people, men constitute about $50.4 \%$ and women $49.6 \%$ (NPC, 2006). Both sexes are responsible for producing the nation's food and one of the major problems confronting mankind in recent times is food crisis. Gender has often been misunderstood as being about the promotion of women only, but gender focuses on the relationship between men and women, their roles, access to and control over resources, division of labour and needs. Gender relations also determine household security, well being of the family, planning, agricultural production and many other aspects of rural life (Frischmuth, 1997). Ayoola and Odiaka (2004) described gender as a socio-economic parameter that is useful in analyzing the roles, responsibilities, opportunities and constraints of both men and women along different ethnic, religion and ecological lines. The term "gender" can also be viewed to economic, social and cultural attributes and opportunities associated with being male or female, (UN-Habitat, 2003). In almost all societies, women and men differ in their activities and undertakings, regarding access to and control over resources and participating in decision-making. Riley (1997) identified gender as a social institution, cultural construct and power tool. There is a danger to confuse "gender" with "women". Sen (1999) posited that the concept of gender is not limited to the male or female species, but goes further to assess the relations between them; as are constantly being renegotiated in the context of changing political, economic, social and cultural environments at the local, national and supra national levels. Gender analysis entails having knowledge of both women and men's roles and responsibilities, as it is the comparative analysis between these that will highlight the gender inequalities of any society. Gender inequality does not imply that all women are worse off than all men; rather, gender (being male or female) is an important social division characterized by inequality. Being a woman or a man influences people's perspectives and their social expectations. Gender equality according to the Canada-Ukraine Gender Fund (2004) means that women and men enjoy the same status and have equal opportunities for realizing their full human rights and potential to contribute to national, political, economic, social, and cultural development, and to benefit from the results. The concept of gender equality acknowledges that different treatment of women and men sometimes required to achieve sameness of results, because of different life conditions or to compensate for past discrimination. UN-Habitat (2003) states that gender analysis must take into consideration and address differentials in control over and access to land and other resources. Gender roles may be productive and social in nature.

Men and women are affected differently in their operation in factors like markets and socio-cultural environments. Women are more constrained than their male counterparts in terms of access to information technology, inputs, credits, etc. Some crops are even classified as man's crop while others are regarded as woman's crop which has an effect on food production. At times, female sex is only restricted to child - bearing and other domestic chores, while their male counterparts do almost all agricultural operations on the farm. Women are responsible for carrying out $70 \%$ of agricultural labour, $50 \%$ of animal husbandry related activities and $60 \%$ of food processing activities (Annon, 2006). Table 1 shows gender participation in some field activities in Nigeria. The table shows that activities differ in relations to task involved. Men performed major role in physical activities like land clearing and tilling, while women major roles were in planting and marketing with almost equal task in weeding operations. In agriculture, men are generally presumed to be the chief actors in agricultural production and, as such, are often the main participants in and/ or recipients of programme-related supports. Although, 
Table 1. Gender participation in farming activities.

\begin{tabular}{lcccc}
\hline \multirow{2}{*}{ Activities } & \multicolumn{2}{c}{ Male } & \multicolumn{2}{c}{ Female } \\
\cline { 2 - 5 } & Frequency $^{*}$ & Percentage $^{*}$ & Frequency $^{*}$ & Percentage \\
\hline Land clearing/stumping & 84 & 76.4 & 26 & 23.6 \\
Tilling/mounding & 98 & 84.5 & 17 & 15.5 \\
Planting/sowing & 53 & 48.2 & 57 & 51.8 \\
Weeding/tending & 56 & 50.9 & 54 & 49.1 \\
Marketing & 21 & 19.0 & 89 & 81.0 \\
Total & 385 & 43.75 & 495 & 56.25 \\
\hline
\end{tabular}

Source: Adu et al. (2003). *Frequency multiple response.

Table 2. Gender involvement in agriculture from 1995 to 2006.

\begin{tabular}{lccccc}
\hline Year & Male & Female & Total & \%Male & \%Female \\
\hline 1995 & 24,444 & 11,759 & 36,203 & 67.52 & 32.48 \\
1996 & 23,385 & 13,059 & 36,894 & 63.38 & 36.2 \\
1997 & 27,191 & 15,608 & 42,799 & 63.53 & 36.47 \\
1998 & 28,887 & 16,099 & 44,986 & 64.21 & 35.79 \\
1999 & 27,109 & 15,627 & 42,736 & 63.43 & 36.57 \\
2000 & 29,763 & 17,331 & 47,094 & 63.2 & 36.8 \\
2001 & 27,765 & 15,893 & 43,658 & 63.6 & 36.4 \\
2002 & 27,173 & 15,589 & 42,762 & 63.54 & 36.45 \\
2003 & 29,310 & 16,368 & 45,678 & 64.17 & 35.83 \\
2004 & 31,195 & 17,426 & 48,621 & 64.16 & 35.84 \\
2005 & 29,413 & 16,420 & 45,833 & 64.17 & 35.83 \\
2006 & 28,435 & 15,875 & 44,310 & 64.17 & 35.83 \\
Grand total & 334,390 & 187,054 & 521,444 & 100 & 100 \\
\hline
\end{tabular}

Source: National Bureau of Statistics 2007.

men and women participate in agriculture, the task may be sex specific but they are complementary and reciprocal. As shown in Table 1, activities such as bush clearing, land preparation, felling of trees, planting of certain crops, hunting, fishing, tending of pasture and care of domestic animals traditionally are often performed by men; whereas, women grow certain crops traditionally, they are also responsible for hoeing, weeding, harvesting, transportation of harvest from farms to their homes, processing, preservation and marketing of crops. They also participate in the care of domestic animals. In spite the contribution of both sexes in food production; unlike men, women's role in promoting economic growth and social stability continues to be inadequately recognized and under-valued.

The factors responsible for these may be due to:

i) The male dominated culture in Nigeria which gives women an inferior position in society.

ii) Customs that forbid women from owing land, taboos and the sexual division of labour which keeps women subordinated to men.

iii) The problem of unpaid productive activities performed by women at the domestic front.

In Nigeria, division of labour within the household is gender specific and according to age, however there are jobs that are characteristically common. Generally, the extent of gender involvement in agricultural production and their contribution to the household food basket vary from one ethnic group to another. For instance, women in Anambra State of Nigeria contribute more than the men in terms of labour input in farming and are solely responsible for household management duties (NAERLS, 2000). In studies elsewhere in Nigeria, involving the Jukun people (Meek, 1981) and the nomadic Fulfude women and Kulka women farmers, between 70 and $80 \%$ of agricultural labour force is represented by women (Ngur, 1987). A survey of peasant agricultural women in northern Nigeria also revealed that rural women take part in income-generating activities, particularly in the processing of agricultural produce. In a related survey of food processing and cottage industries by Simmons (1973) in three Zaria villages, he observed that $90 \%$ of the women were involved in at least one food processing activity or the other. Table 2 gives the trend in gender 
involvement in agriculture in Nigeria between 1995 and 2006. The table revealed that the male involvement in agricultural production was highest in 1995 at $68 \%$ as against female involvement which was $32 \%$. However, despite the continuous increase in the country's population growth rate, male involvement in agriculture continued to decline to about $64 \%$ from 2006 while the involvement of female in agriculture was on the increase, rose from $32 \%$ in 1995 to $36 \%$ in 2006 . The implication of this is that, despite the current global food crisis, Nigeria men especially the youth that are suppose to embrace farming are neglecting agriculture and probably migrating from the rural village to the cites in search of white collar jobs, while the women still remain and engaged in agriculture despite their dual roles as farmers and mothers. This assertion was confirmed by Lawanson (2010) who reported that women constitute the major actors in all aspects of life. Ogunlela and Mukhtar (2009) in their study stated that the role that women play and their position in meeting the challenges of agricultural production and development are quite dominant and prominent. Their relevance and significance, therefore, cannot be overemphasized (Nnadozie and lbe, 1996; Rahman, 2008).

Findings from a study financed by the United Nations Development Programme (UNDP) revealed that women make up some 60 to $80 \%$ of agricultural labour force in Nigeria (World Bank, 2003), depending on the region and they produce two-thirds of the food crops. Yet, in spite of these, widespread assumption that men - and not women -make the key farm management decisions has prevailed. Sadly, female farmers in the country are among the voiceless, especially with respect to influencing agricultural policies. Such policies which are aimed at increasing food security and food production tend to either underestimate or totally ignore women's role in both production and the general decision-making process within the household. They work as farmers, as traders, as home managers etc. or combination of two or more of these activities. Akankpo and Asa (2006) also confirmed these trends in gender involvement in agriculture in the Eastern part of the country that female are more involved in agriculture than male. In order to guide against persistent food crisis that may lead to hunger and starvation, various governments since 1970s have evolved in various programmes aimed at boosting agricultural production in Nigeria. Most of these programmes are Operation Feed the Nation (OFN), Green Revolution Programme (GRP), Go Back to Land programme, all these were dominated by men. But on the other hand, the Better life for Rural Women programme, Family Support Programme and Family Economic Advancement Programme (FEAP) contributed immensely to social upliftment and improved status of the rural women. Therefore, empowering the rural women will enable them take greater control of their own lives and put more efforts on agricultural activities such as planting, weeding, supply of water for irrigation, harvesting, threshing, winnowing, tending poultry and animals as their male counterparts.

\section{Conclusion and Recommendations}

Food sufficiency can only be guaranteed by continued gender involvement in agriculture. There is therefore, the need for an aggressive approach to ensure that gender participation in agriculture is at an increasing rate. Also, government agricultural policies and programs should not be gender specific. The importance of agriculture cannot be ignored. Therefore, for Nigeria to be able to feed her citizen and get out of this food crisis the following measures are suggested:

i) There should not be gender disparity or gender bias in agricultural policies and programmes.

ii) Government should invest more on education since development in all spheres of life including agriculture hinges on education of the people.

iii) Women involvement in agriculture is on the increase compared to men, therefore they should be given appropriate types of technology to cater for the labour intensive farm activities, good financial support and access to more farm land through appropriate land reforms.

iv) Farm inputs and other innovations should be available to farmers at affordable and subsidized rates as and when needed.

v) For food security, gender division of labour according to tasks should be discarded and there should be equity in every aspect of agricultural activities.

vi) Support systems for farmers within a holistic gendersensitive framework are urgently needed to form a policy development agenda.

\section{REFERENCES}

Akankpo GO, Asa UA (2006). Gender Role in Maize Production in Ini L.G.A. Akwa Ibom State. Proceeding of $40^{\text {th }}$ Annual Conference of ASN held at Umudike. Pp 606-609.

Annon (2006). National Gender Policy; Federal Ministry of Women Affairs and Social Development printed by Amana printing limited Kaduna. Pp 7-14.

Ayoola JB, Odiaka EC (2004). Gender perspectives on Agricultural Development. Experience from Benue State of Nigeria. Proceeding of $38^{\text {th }}$ Annual Conference of ASN, Nasara $P$.

CBN (2006). Central Bank of Nigeria Statistical Bulletin.

Frischmuth C (1997). Gender is not a sensitive issue; Institutionalizing a Gender - oriented participatory Approach in Savionga, Zambia, state keeper series No 72.

Lawanson TO (2010). Gender Differentials in Nigeria: Implications for Sustainable Urban development. Department of Urban and Regional Planning, University of Lagos Akoka Lagos

Meek C (1981). A Sudanese Kingdom, London: Kegan, Paul, Trench, Trubner and Co.

NAERLS (2000). An assessment of contribution of women to family farming in north- eastern Nigeria. Report of a research sponsored by the National Agricultural Research Programme, Abuja, Nigeria. 
National Agricultural Extension and Research Liaison Service, Ahmadu Bello University, Zaria, Nigeria.

NBS (2007): National Bureau of Statistics; Agricultural Survey Report 1994-2006. Produced under the Auspices the Economic Reforms and Government Project (ERGP) Pp. 60-71.

Ngur N (1987). Women and development in crop and livestock production in Nigeria. Paper presented at the seminar on Women Studies, University of Ibadan, Nigeria. pp. 4-6 November 1987.

Nnadozie B, I lbe (1996). Women in agriculture: Problems and prospects, In: Agricultural Transformation in Nigeria, Eds., A. C. Nwosu; C. U. Nwajuba and J. A. Mbanasor. Owerri, Nigeria: Novelty Industrial Enterprises.

NPC (2006). National Population Commission.

Rahman SA (2008). Women's involvement in agriculture in northern and southern Kaduna State. J. Gend. Stud., 17: 17-26.

Riley NE (1997). Gender, Power and Population Change Population Bulletin, Vol. 52 No. 1 (Washington, D.C. Population).
Simmons EB (1973). The economics of consumer-oriented food processing technologies in FAO. Rev. Agric. Dev., 75(13): 40-41.

World Bank (2003). Nigeria: Women in agriculture, In: Sharing Experiences-Examples of Participating Approaches. The World Bank Group. The World Bank Participating Sourcebook, Washington, D.C.http:/www.worldbank.org/wbi/publications.htm 